\title{
De waarde van de DASS bij verzuimbeleid: sensitiviteit en specificiteit van een psychopathologie-maat
}

\author{
Veerle Brenninkmeijer*, Roland W.B. Blonk*, Karen Nieuwenhuijsen** \\ \& Edwin de Beurs***
}

In het huidige onderzoek wordt onderzocht in hoeverre de DASS (Depression Anxiety Stress Scales) weet te discrimineren tussen gezonde mensen, mensen met een stressgerelateerde stoornis en mensen met ernstigere psychopathologie (angst- of stemmingsstoornis). Verschillen tussen groepen zijn eerst onderzocht met een one-way analyse. Door middel van ROC-curves is vervolgens het discriminerend vermogen van de DASS en de bijbehorende afkappunten bepaald. Deze studie toont het discriminerend vermogen van de DASS-42 en DASS-21 aan voor het detecteren van een stressgerelateerde stoornis, een klinische angststoornis en depressie. Voor de arbocuratieve zorg is de DASS derhalve een zeer bruikbaar instrument dat een effectieve inzet kan bevorderen van interventies voor zieke werknemers.

Trefwoorden: DASS (Depression Anxiety Stress Scales), stressgerelateerde stoornis, klinische angststoonis, depressie, verzuimbeleid

\section{Inleiding}

Bijna een kwart van het ziekteverzuim en ongeveer eenderde van de WAOintrede wordt veroorzaakt door psychische klachten (NCvB, 2003; UWV, 2003). Deze psychische klachten lopen uiteen van stressgerelateerde klachten tot ernstige klinische problematiek, zoals stemmings- en angststoornissen. In de dagelijkse praktijk is men nog steeds op zoek naar handzame instrumenten die professionals kunnen ondersteunen in het beoordelen en diagnosticeren van deze verschillende soorten psychische klachten. Met name in de arbocuratieve sector is het van groot belang om snel en op een relatief makkelijke manier tot een eerste diagnose te komen, zodanig dat interventies tijdig en effectief kunnen worden ingezet om werkhervatting te bevorderen.

In de richtlijnen voor bedrijfsartsen van de NVAB (2000), de Nederlandse Vereniging voor Arbeids- en Bedrijfsgeneeskunde, wordt de beoordeling van de ernst en de complexiteit van psychische klachten van verzuimende werknemers dan ook als eerste stap gezien. Om het risico van langdurig ziekteverzuim in te kunnen schatten en langdurig verzuim te kunnen voorkomen, is

\footnotetext{
*TNO Kwaliteit van Leven, Hoofddorp, ** Coronel Instituut, AMC, *** Leids Universitair Medisch Centrum. Correspondentieadres: Dr. V. Brenninkmeijer, TNO Kwaliteit van Leven, Postbus 718, 2130 AS Hoofddorp. E-mail: v.brenninkmeijer@arbeid.tno.nl

Wij danken Dr. Femke T.C. Bennenbroek voor haar waardevolle suggesties en adviezen ter verbetering van dit manuscript.
} 
het van groot belang om snel te bepalen of er bij de werknemer sprake is van een psychische aandoening. Is dat het geval, dan is de volgende stap onderscheid maken tussen stressgerelateerde stoornissen en ernstigere psychopathologie, zoals een angst- of stemmingsstoornis.

Er zijn belangrijke overeenkomsten, maar ook verschillen tussen een stressgerelateerde stoornis, een depressie en een angststoornis. De stressgerelateerde stoornis heeft een klachtenpatroon bestaande uit een aantal van de volgende klachten: vermoeidheid, lusteloosheid, gevoelens van overbelasting, piekeren, prikkelbaarheid, slaapproblemen, concentratieproblemen, gedrukte stemming (zie richtlijn 'sociaal-medisch handelen bij psychische klachten' van de Nederlandse Vereniging voor Arbeids-en Bedrijfsgeneeskunde, NVAB, 2000). De NVAB onderscheidt drie varianten van stressgerelateerde stoornissen: spanningsklachten, overspannenheid en burnout. Een stressgerelateerde stoornis wordt gezien als een minder ernstige vorm van psychopathologie dan depressie of een angststoornis. Belangrijke kenmerken van depressie zijn een depressieve stemming en een verlies van belangstelling voor, of plezier in gebeurtenissen of activiteiten (zie bijv. Van de Hoofdakker, Albersnagel \& Ormel, 1989). Belangrijkste kenmerk van angst is buitensporige angst of bezorgdheid (zie bijv. NVAB, 2000). Het tripartiete model van Clark en Watson (1991) benadrukt zowel de overeenkomsten als de verschillen tussen angst- en depressiesymptomen. Zowel angst als depressie gaat gepaard met algemene malaise (distress), waaronder prikkelbaarheid en spanningsklachten. Daarentegen is fysiologische hyperarousal alleen aanwezig bij angst. Afwezigheid van positief affect is alleen aanwezig bij depressie.

Door in een vroeg stadium te bepalen of er sprake is van een stressgerelateerde stoornis, een depressie of een angststoornis, kunnen interventies om herstel en werkhervatting te bevorderen effectiever worden ingezet. In het geval van een stressgerelateerde stoornis kan de bedrijfsarts besluiten zelf de behandeling van de zieke werknemer op zich te nemen (zie ook NVAB, 2000). Uit onderzoek blijkt dat een activerende begeleiding van de bedrijfsarts gunstige effecten heeft op het klachtniveau en de verzuimduur van werknemers met een stressgerelateerde stoornis (Van der Klink, Blonk, Schene \& Van Dijk, 2003). Als het echter om ernstigere klachten gaat (bijvoorbeeld om een klinische angststoornis of een depressie), dan dient de bedrijfsarts door te verwijzen naar de GGZ, zoals beschreven in de NVAB-richtlijnen voor bedrijfsartsen.

Bij het detecteren van, en het onderscheid maken tussen stressgerelateerde stoornissen, klinische angststoornissen en depressie zouden de Depression Anxiety Stress Scales (DASS; Lovibond \& Lovibond, 1995a; zie ook Brown, Chorpita, Korotitsch \& Barlow, 1997) een belangrijke rol kunnen spelen. Deze van oorsprong Australische schaal heeft belangrijke overeenkomsten met het tripartiete model van Clark en Watson (1991). Het instrument is inmiddels in verscheidene talen vertaald, waaronder in het Nederlands (De Beurs, Van Dyck, Marquenie, Lange \& Blonk, 2001). In verschillende studies is de psychometrische kwaliteit van de Nederlandse versie van de DASS onderzocht en aangetoond (De Beurs, Van Dyck, Marquenie, Lange \& Blonk, 2001; Nieuwenhuijsen, De Boer, Verbeek, Blonk \& Van Dijk, 2003). Uit deze studies blijkt dat de drie schalen van de DASS bij zowel gezonde als klinische populaties de verschillende symptomen van psychische klachten goed in kaart weten te brengen. De interne consistentie van de drie subschalen is goed: Cronbachs alfa varieert van 0.81 tot 0.97 . Daarnaast is de criterium- en constructvaliditeit bij verschillende populaties goed (De Beurs, Van Dyck, Marquenie, Lange \& Blonk, 2001; Nieuwenhuijsen, De Boer, Verbeek, Blonk \& Van Dijk, 2003). 
Aangezien er vanuit de praktijk behoefte bestond aan een zo kort mogelijk instrument, is er een verkorte versie van de DASS geconstrueerd, de DASS-21 (Lovibond \& Lovibond, 1995a), bestaande uit 21 van de oorspronkelijke 42 items. Bij de constructie van de DASS werden de drie subschalen onderverdeeld in 16 groepen (zeven groepen depressie-items, vier groepen angst-items en vijf groepen stress-items). Voor de verkorte versie werden van de 16 groepen de hoogst ladende items geselecteerd, om zo de drie subschalen samen te stellen (Lovibond \& Lovibond, 1995b). Bij de constructie van de Nederlandse DASS-2 1 is dezelfde procedure gevolgd, maar in de Nederlandse versie is zeven keer voor een ander item gekozen dan in de Engelse verkorte DASS. Uit onderzoek blijkt dat de betrouwbaarheid van de verkorte (Nederlandse) versie vergelijkbaar is met de langere versie van de DASS (De Beurs et al., 2001).

In het huidige onderzoek staat het discriminerend vermogen van de DASS centraal. Onderzocht wordt in welke mate de DASS gebruikt kan worden bij het onderscheid maken tussen:

1 gezonde personen en personen met een stressgerelateerde aandoening;

2 personen met een stressgerelateerde aandoening en personen met een angststoornis;

3 personen met een stressgerelateerde aandoening en personen met een depressieve stoornis.

In een eerdere Nederlandse studie is het onderscheidend vermogen onderzocht voor het detecteren van mensen met een angststoornis of depressie binnen een populatie van zieke werknemers met psychische klachten (Nieuwenhuijsen, De Boer, Verbeek, Blonk \& Van Dijk, 2003). De resultaten van deze studie laten zien dat de DASS geschikt is om angst en depressie te detecteren, en te onderscheiden van een stressgerelateerde stoornis. De waarde van het huidige onderzoek is gelegen in het feit dat er gebruik wordt gemaakt van een bredere range van psychopathologie, variërend van gezonde mensen tot patiënten van een polikliniek van een psychiatrisch ziekenhuis. Zo kunnen we niet alleen het onderscheid tussen gezonde personen en personen met een stressgerelateerde stoornis onderzoeken, maar ook het onderscheid tussen personen met een stressgerelateerde stoornis en personen met klinische angst of depressie. Bij de vergelijking tussen groepen zijn mensen waarbij sprake was van comorbiditeit (angst én depressie) achterwege gelaten. Op deze wijze wordt de zuiverheid van de diagnostische groepen zoveel mogelijk bevorderd.

Eerst wordt onderzocht in hoeverre bovengenoemde groepen verschillend scoren op de DASS-schalen. Daarna wordt het onderscheidend vermogen van de DASS bepaald en worden afkappunten berekend. Een afkappunt kan beschouwd worden als een 'grensscore' tussen verschillende diagnosegroepen. Met behulp van de afkappunten kan men mensen op grond van hun DASSscore indelen in verschillende diagnosegroepen. Voor elke DASS-schaal zullen meerdere mogelijke afkappunten worden gepresenteerd, waarbij per afkappunt de sensitiviteit en de specificiteit worden weergegeven. Sensitiviteit refereert aan de kans dat iemand met een bepaalde stoornis inderdaad als zodanig wordt gekwalificeerd. Specificiteit verwijst naar de kans dat iemand zonder stoornis als zodanig wordt gekwalificeerd. Voor de huidige studie wordt met name de sensitiviteit van belang geacht. De consequenties van stoornissen over het hoofd zien is bij het overwegen of een behandelaanbod moet worden gedaan, ernstiger dan het onterecht concluderen dat er wel sprake is van een stoornis. Desalniettemin is ook de specificiteit van groot belang. Een hoge mate van specificiteit is belangrijk teneinde onnodige medicalisering tegen te gaan. In dit onderzoek wordt gestreefd naar een sensitiviteit van 
minimaal .80, een gangbare normwaarde voor de power van een onderzoek (Cohen, 1977). De sensitiviteit kan men beschouwen als de power van een test. Afhankelijk van de sensitiviteit en de specificiteit die men nastreeft, kan men ook een eigen keuze maken uit de gepresenteerde afkappunten.

Het discriminerend vermogen van zowel de DASS-42 en DASS-21 zal onderzocht worden. Als het onderscheidend vermogen van de DASS-21 vergelijkbaar is met de DASS-42, dan zou de verkorte (minder belastende) vragenlijst een zeer geschikte eerste stap in een ketenanalyse kunnen zijn. Bij zieke werknemers waarbij het vermoeden bestaat dat psychische klachten een rol spelen, wordt dan de (verkorte) DASS afgenomen. Bij een score (gelijk of) boven de grenswaarde kan men vervolgens een ander instrument inzetten dat zich specifiek richt op het diagnosticeren van een klinische depressie of een klinische angststoornis.

\section{Methode}

\subsection{Proefpersonen en procedure}

Proefpersonen werden geselecteerd uit drie verschillende databestanden.

1 Het eerste databestand betreft een cohortbestand van 501 gezonde personen (zelfstandig ondernemers) die zich bij een verzekeringsmaatschappij voor arbeidsongeschiktheid hadden verzekerd (zie Lagerveld, Blonk, De Croon \& Houtman 2004). Deelnemers werden geselecteerd als er bij de verzekeringsmaatschappij geen claim lag wegens ziekte/arbeidsongeschiktheid. Vragenlijsten werden verstuurd naar een random steekproef van 1901 zelfstandig ondernemers. Er werden in totaal 560 vragenlijsten teruggestuurd (een response rate van $29 \%$ ). Van deze 560 deelnemers hadden 59 personen $(11 \%)$ de lijst niet of slechts zeer beperkt ingevuld. Uiteindelijk bleven er 501 bruikbare lijsten over. Deze steekproef bestond voor $82 \%$ uit mannen. De gemiddelde leeftijd was 41 jaar $(S D=9,0)$. Proefpersonen in deze dataset waren niet gediagnosticeerd. Bij deze 'gezonde' populatie werd aangenomen dat er geen psychische aandoeningen aanwezig waren.

2 Het tweede bestand betreft 153 zieke personen (zelfstandig ondernemers) met psychische klachten (zie ook Blonk, Lagerveld, Brenninkmeijer \& Houtman, 2004). Deze personen werden via dezelfde verzekeringsmaatschappij geselecteerd als de personen uit het eerste databestand (Lagerveld et al., 2004). Deelnemers werden geselecteerd wanneer zij bij de verzekeringsmaatschappij een claim hadden ingediend wegens ziekte/arbeidsongeschiktheid als gevolg van psychische klachten. De steekproef bestond oorspronkelijk uit 153 personen: 32 vrouwen en 121 mannen. De gemiddelde leeftijd was 42 jaar $(S D=8,1)$. Proefpersonen werden gediagnosticeerd door de onderzoekers met behulp van een verkorte telefonische versie van de het Composite International Diagnostic Interview (CIDI: WHO, 1997). De onderzoekers hadden voor telefonische afname gekozen vanwege de aangetoonde vergelijkbaarheid met face-to-face interviews en om praktische redenen (zie bijv. Fenig, Levav, Kohn \& Yelin, 1993). Het telefonische interview omvatte de volgende diagnosen: sociale fobie, paniekstoornis, somatoforme stoornis, posttraumatische stressstoornis, obsessieve/dwangstoornis, depressie in engere zin, bipolaire stoornis en psychose. Een angststoornis werd geconcludeerd als proefpersonen voldeden aan de criteria voor een sociale fobie, paniekstoornis, somatoforme 
stoornis, posttraumatische stressstoornis of obsessieve/dwangstoornis. Aangezien personen verzuimden als gevolg van psychische klachten, werd geconcludeerd dat er sprake was van een stressgerelateerde stoornis indien men niet voldeed aan één van de CIDI-diagnosen. Personen bij wie een andere stoornis dan angst, depressie of stressgerelateerde stoornis werd geconcludeerd, of mensen bij wie sprake was van angst én depressie (comorbiditeit), werden niet meegenomen in de huidige studie. Van de 153 personen hadden vier mensen een depressie, vijf een angststoornis en 145 een stressgerelateerde stoornis (bij één persoon was sprake van comorbiditeit). Voor de huidige studie zijn alleen de data van de voormeting gebruikt, de overige meetmomenten zijn buiten beschouwing gelaten. Daarnaast beperkt het huidige onderzoek zich tot mensen bij wie angst, depressie of een stressgerelateerde stoornis werd gediagnosticeerd (zonder comorbiditeit). Het uiteindelijke aantal personen dat in de huidige studie is geïncludeerd, bedraagt 150 .

3 Het derde bestand betreft een bestand van 192 zieke werknemers met psychische klachten (zie ook Nieuwenhuijsen et al., 2003). Gegevens over deze werknemers werden verzameld door dertig bedrijfsartsen, werkzaam bij negen verschillende arbodiensten door heel Nederland. Het ging hierbij om personen die 100\% verzuimden als gevolg van psychische problemen. Daarnaast was er een aantal andere inclusiecriteria, zoals de duur van het verzuim (< zes weken), telefonische bereikbaarheid en het beheersen van de Nederlandse taal. De steekproef bestond oorspronkelijk uit 121 vrouwen en 71 mannen. De gemiddelde leeftijd was 44 jaar $(S D=8,6)$. De diagnose werd gesteld op dezelfde wijze als in het tweede bestand, door middel van een verkorte telefonische versie van de CIDI (WHO, 1997). Van de 192 personen hadden 44 mensen een depressie, 38 een angststoornis, 127 een stressgerelateerde stoornis en 7 een psychose (bij sommige mensen was sprake van comorbiditeit). Het huidige onderzoek beperkt zich tot mensen bij wie angst, depressie of een stressgerelateerde stoornis werd geconcludeerd (zonder comorbiditeit). Het uiteindelijke aantal personen dat in de huidige studie is geïncludeerd, bedraagt 179 .

4 Het vierde bestand betreft een bestand van 173 patiënten van een polikliniek van een psychiatrisch ziekenhuis (zie ook De Beurs et al., 2001). Deze steekproef bestond oorspronkelijk uit 110 vrouwen en 63 mannen. De gemiddelde leeftijd was 39 jaar $(S D=9,1)$. Proefpersonen waren gediagnosticeerd door de behandelend psycholoog of psychiater op grond van zijn/haar klinisch oordeel. In het klinisch oordeel werden de DSM-IV-criteria (APA, 1994) gebruikt. Van de 173 personen hadden 53 mensen (ten tijde van het onderzoek of bij aanmelding) een paniekstoornis met agorafobie, 19 een sociale fobie, 15 een compulsief-obsessieve stoornis, 30 een depressie (plus 14 depressie als nevendiagnose), 2 dystymie, en 54 hadden een overige stoornis, meestal een angststoornis (bij sommige mensen was sprake van comorbiditeit). Mensen bij wie op het moment van het onderzoek een angst- of stemmingstoornis aanwezig was (zonder comorbiditeit), werden in het huidige onderzoek meegenomen. Het uiteindelijke aantal personen dat is geïncludeerd, bedraagt 79 .

De uiteindelijke onderzoeksgroep bestond in totaal uit 909 personen: 286 vrouwen en 622 mannen (van één persoon was het geslacht niet bekend). De gemiddelde leeftijd was 42 jaar $(S D=8,9)$. De verdeling van de diagnosegroepen was als volgt: 501 personen hadden geen psychische stoornis, 270 personen hadden een stressgerelateerde stoornis, 87 personen hadden een angststoornis en 51 personen hadden een depressieve stoornis. 


\subsection{Instrumenten}

Psychische klachten. Psychische klachten werden gemeten met de Nederlandse vertaling van de Depression Anxiety Stress Scales (DASS-42: De Beurs et al., 2001). Deze schaal omvat 42 items: 14 voor depressie, 14 voor angst en 14 voor stress. Voorbeelditems zijn: 'Ik voelde me verdrietig en depressief' (depressie); 'Ik voelde me ontzettend angstig' (angst); en 'Ik was erg opgefokt' (stress). Respondenten wordt gevraagd aan te geven in hoeverre de items de afgelopen week op hen van toepassing waren. Items kunnen beantwoord worden op een Likert-schaal die loopt van 0 (helemaal niet of nooit van toepassing) tot 3 (zeer zeker of meestal van toepassing). Schaalscores worden berekend door de scores op de items van de desbetreffende schaal op te tellen. De interne consistentie van de depressie-, angst- en stressschalen van de DASS42 bleek in dit onderzoek goed te zijn (Cronbachs alfa is resp. .97, .93 en .96). De verkorte DASS (DASS-21) omvat 21 items die afkomstig zijn uit de DASS-42: 7 voor depressie, 7 voor angst en 7 voor stress. Ook van deze verkorte versie van de DASS waren de schalen intern consistent (Cronbachs alfa resp. .94, .88 en .93).

\subsection{Analyses}

Om te onderzoeken in hoeverre de diagnosegroepen verschillen op de DASSschalen, is een one-way variantieanalyse uitgevoerd met diagnosegroep als onafhankelijke variabele (geen psychische aandoening, stressgerelateerde stoornis, angst-, en depressiestoornis) en de verschillende DASS-schalen als afhankelijke variabelen. Post-hoc-analyses werden uitgevoerd om te bepalen welke groepen significant van elkaar verschillen. Voor het toetsen van de contrasten is gekozen voor de optie LSD (least significant difference).

Om afkappunten te bepalen zijn ROC (Receiver Operator Characteristic) curves berekend. Bij een ROC-curve wordt de sensitiviteit (true positive rate) afgezet tegen 1-specificiteit (false positive rate) voor verschillende afkappunten van een schaal. Het gebied onder de curve (AUC: Area under the Curve) geeft een indicatie voor het discriminerend vermogen van de schaal. Het onderscheidend vermogen van een schaal is groter naarmate de curve meer langs de linkerbovenhoek van de figuur loopt. Er zijn ROC-curves berekend voor het onderscheiden van:

1 gezonde personen en personen met een stressgerelateerde aandoening;

2 personen met een stressgerelateerde aandoening en personen met een angststoornis;

3 personen met een stressgerelateerde aandoening en personen met een depressie.

\section{Resultaten}

In tabel 1 staan de gemiddelden en standaarddeviaties /of verdeling in percentage) weergegeven van de uitgebreide DASS-schalen, leeftijd en geslacht, voor de verschillende databestanden afzonderlijk en gezamenlijk.

\subsection{Verschillen tussen diagnosegroepen ${ }^{1}$}

In tabel 2 staan de gemiddelden en standaarddeviaties op de DASS-schalen voor verschillende diagnosegroepen weergegeven.

Depressie-subschalen. Op zowel de uitgebreide als de verkorte depressieschaal bleken de diagnosegroepen significant van elkaar te verschillen $(F(3,875)=225.67, p<.05$ en $F(3,883)=208.53, p<.05)$. Op beide schalen scoorde de groep met een depressieve aandoening significant hoger dan de 
Tabel 1 Gemiddelden en standaarddeviaties (of verdeling in percentage) van de uitgebreide DASS-schalen, leeftijd en geslacht, voor de verschillende databestanden afzonderlijk en gezamenlijk

\begin{tabular}{|c|c|c|}
\hline Bestand 1 (Lagerveld et al., 2004; $N=501$ ) & $M / \%$ & $S D$ \\
\hline $\begin{array}{l}\text { Leeftijd } \\
\text { Geslacht (\% man) } \\
\text { Depressieschaal (14 items) } \\
\text { Angstschaal ( } 14 \text { items) } \\
\text { Stressschaal (14 items) }\end{array}$ & $\begin{array}{l}41,10 \\
82 \% \\
3,39 \\
1,79 \\
5,49\end{array}$ & $\begin{array}{l}9,03 \\
- \\
4,69 \\
3,04 \\
5,04\end{array}$ \\
\hline Bestand 2 (Blonk et al., 2004; $N=150$ ) & $M / \%$ & $S D$ \\
\hline $\begin{array}{l}\text { Leeftijd } \\
\text { Geslacht (\% man) } \\
\text { Depressieschaal ( } 14 \text { items) } \\
\text { Angstschaal (14 items) } \\
\text { Stressschaal (14 items) }\end{array}$ & $\begin{array}{l}42,22 \\
79 \% \\
17,44 \\
10,61 \\
19,97\end{array}$ & $\begin{array}{l}8,18 \\
- \\
9.45 \\
7,68 \\
8,72\end{array}$ \\
\hline Bestand 3 (Nieuwenhuijsen et al., 2003; $N=179$ ) & $M / \%$ & $S D$ \\
\hline $\begin{array}{l}\text { Leeftijd } \\
\text { Geslacht (\% man) } \\
\text { Depressieschaal ( } 14 \text { items) } \\
\text { Angstschaal (14 items) } \\
\text { Stressschaal (14 items) }\end{array}$ & $\begin{array}{l}44,21 \\
39 \% \\
15,51 \\
9,41 \\
18,47\end{array}$ & $\begin{array}{l}8,58 \\
- \\
9,71 \\
7,27 \\
9,16\end{array}$ \\
\hline Bestand 4 (de Beurs et al., 2001; N = 79) & $M / \%$ & $S D$ \\
\hline $\begin{array}{l}\text { Leeftijd } \\
\text { Geslacht (\% man) } \\
\text { Depressieschaal ( } 14 \text { items) } \\
\text { Angstschaal ( } 14 \text { items) } \\
\text { Stressschaal (14 items) }\end{array}$ & $\begin{array}{l}44,37 \\
30 \% \\
15,80 \\
15,21 \\
18,36\end{array}$ & $\begin{array}{l}9,28 \\
- \\
12,59 \\
10,70 \\
10,12\end{array}$ \\
\hline Totale bestand $(N=909)$ & $M / \%$ & $S D$ \\
\hline $\begin{array}{l}\text { Leeftijd } \\
\text { Geslacht (\% man) } \\
\text { Depressieschaal ( } 14 \text { items) } \\
\text { Angstschaal ( } 14 \text { items) } \\
\text { Stressschaal (14 items) }\end{array}$ & $\begin{array}{l}41,87 \\
69 \% \\
9,22 \\
5,90 \\
11,34\end{array}$ & $\begin{array}{l}8,90 \\
- \\
10,03 \\
7,60 \\
9,71\end{array}$ \\
\hline
\end{tabular}

andere groepen (zie tabel 2). De gezonde groep scoorde significant lager dan de andere groepen. De groepen stress vs. angst bleken niet significant van elkaar te verschillen.

Angst-subschalen. De diagnosegroepen bleken significant van elkaar te verschillen op zowel de uitgebreide als de verkorte angstschaal $(F(3,874)=202.08$, $p<.05$ en $F(3,884)=197.96, p<.05)$. Op beide schalen scoorde de groep met angststoornissen significant hoger dan de overige groepen (zie tabel 2). De gezonde groep scoorde significant lager dan de andere groepen.

Stress-subschalen. De diagnosegroepen bleken significant van elkaar te verschillen op de uitgebreide en verkorte stressschaal $(F(3,861)=241.42, p<.05$ en $F(3,875)=249.27, p<.05)$. De groep met een stressgerelateerde stoornis scoorde significant hoger dan de gezonde groep op zowel de uitgebreide als de verkorte stressschaal (zie tabel 2). De stressgroep scoorde echter niet significant hoger dan de angst- of depressieve groep. De gezonde groep scoorde opnieuw significant lager dan de andere groepen. 
Tabel 2 Gemiddelden en standaarddeviaties op de DASS-schalen voor de verschillende diagnosegroepen

\begin{tabular}{|c|c|c|c|c|}
\hline DASS-subschaal & Diagnose & $M$ & $S D$ & $N$ \\
\hline Depressieschaal (14 items) & $\begin{array}{l}\text { Gezond } \\
\text { Stress } \\
\text { Angst } \\
\text { Depressie }\end{array}$ & $\begin{array}{l}3,39^{a} \\
15,52^{b} \\
14,92^{b} \\
22,64^{c}\end{array}$ & $\begin{array}{l}4,69 \\
9,49 \\
10,93 \\
10,76\end{array}$ & $\begin{array}{l}482 \\
263 \\
84 \\
50\end{array}$ \\
\hline Depressieschaal (7 items) & $\begin{array}{l}\text { Gezond } \\
\text { Stress } \\
\text { Angst } \\
\text { Depressie }\end{array}$ & $\begin{array}{l}1,54^{a} \\
7,47^{b} \\
7,18^{b} \\
11,33^{c}\end{array}$ & $\begin{array}{l}2,37 \\
4,94 \\
5,70 \\
5,70\end{array}$ & $\begin{array}{l}486 \\
266 \\
84 \\
51\end{array}$ \\
\hline Angstschaal (14 items) & $\begin{array}{l}\text { Gezond } \\
\text { Stress } \\
\text { Angst } \\
\text { Depressie }\end{array}$ & $\begin{array}{l}1,79 \mathrm{a} \\
9,27^{b} \\
15,38^{c} \\
12,39^{d}\end{array}$ & $\begin{array}{l}3,04 \\
7,32 \\
9,77 \\
8,69\end{array}$ & $\begin{array}{l}484 \\
261 \\
84 \\
49\end{array}$ \\
\hline Angstschaal (7 items) & $\begin{array}{l}\text { Gezond } \\
\text { Stress } \\
\text { Angst } \\
\text { Depressie }\end{array}$ & $\begin{array}{l}0,89 \mathrm{a} \\
5,11 \mathrm{~b} \\
8,10^{c} \\
6,92^{d}\end{array}$ & $\begin{array}{l}1,74 \\
4,11 \\
5,25 \\
4,78\end{array}$ & $\begin{array}{l}487 \\
265 \\
86 \\
50\end{array}$ \\
\hline Stressschaal (14 items) & $\begin{array}{l}\text { Gezond } \\
\text { Stress } \\
\text { Angst } \\
\text { Depressie }\end{array}$ & $\begin{array}{l}5,49 \mathrm{a} \\
18,34 \mathrm{~b} \\
18,60 \mathrm{~b} \\
20,41^{b}\end{array}$ & $\begin{array}{l}5,04 \\
9,15 \\
9,91 \\
8,02\end{array}$ & $\begin{array}{l}481 \\
252 \\
81 \\
51\end{array}$ \\
\hline Stressschaal (7 items) & $\begin{array}{l}\text { Gezond } \\
\text { Stress } \\
\text { Angst } \\
\text { Depressie }\end{array}$ & $\begin{array}{l}2,71 \mathrm{a} \\
9,66 \mathrm{~b} \\
9,41 \mathrm{~b} \\
10,67 \mathrm{~b}\end{array}$ & $\begin{array}{l}2,73 \\
4,73 \\
5,30 \\
4,24\end{array}$ & $\begin{array}{l}483 \\
260 \\
85 \\
51\end{array}$ \\
\hline
\end{tabular}

NB: groepen met gelijk superscript verschillen niet significant, groepen met ongelijk superscript verschillen wel significant $(\operatorname{LSD}, p<.05)$

\subsection{Afkappunten DASS}

Afkappunten DASS-42 voor detecteren stressgerelateerde aandoening. Figuur 1 geeft de ROC-curves weer van de subschalen van de reguliere DASS voor het detecteren van mensen met een stressgerelateerde aandoening vergeleken met een groep gezonde mensen. Het discriminerend vermogen van de depressie-, angst- en stressschalen van de DASS-42 bleek goed: het gebied onder de curve, als indicatie voor het discriminerend vermogen, was respectievelijk $.89, .86$ en .89. Over het algemeen wordt een waarde van .70 of hoger acceptabel geacht (Hosmer \& Lemeshow, 2000). Tabel 3 geeft de afkappunten weer van de subschalen van de reguliere DASS, alsmede de sensitiviteit en de specificiteit, voor het detecteren van mensen met een stressgerelateerde aandoening (onderscheid gezond vs. stressgerelateerde aandoening). Afhankelijk van de sensitiviteit en de specificiteit die men nastreeft, kan men een keuze maken uit de gepresenteerde afkappunten.

Afkappunten DASS-21 voor detecteren stressgerelateerde aandoening. Het discriminerend vermogen van de depressie-, angst- en stressschalen van de DASS-21 voor het detecteren van een stressgerelateerde aandoening is vergelijkbaar met dat van de DASS-42: het gebied onder de curve was respectievelijk .87, .84 en .89 . Tabel 4 geeft de sensitiviteit en de specificiteit van moge- 
Discriminerend vermogen DASS

\section{ROC curves DASS-42}

Criterium: stressgerelateerde stoornis

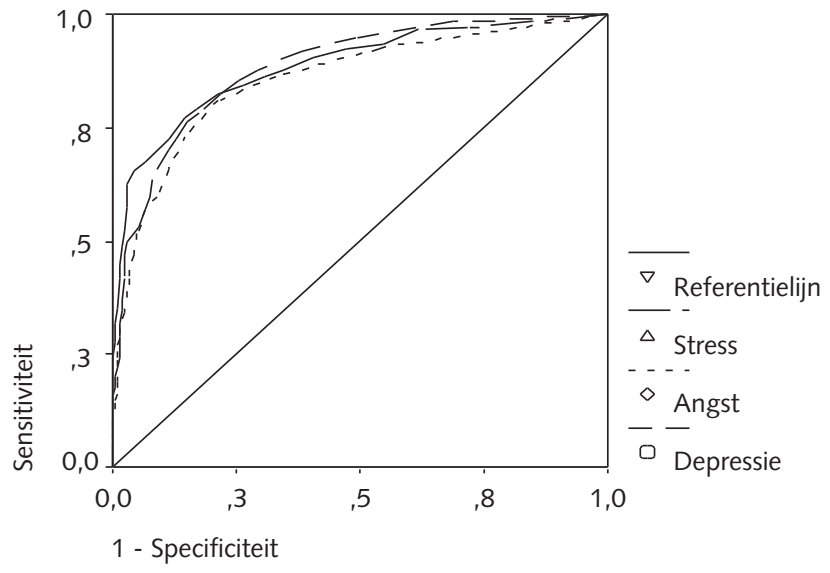

Figuur 1 ROC-curves van de DASS-42-subschalen voor het detecteren van mensen met een stressgerelateerde aandoening (onderscheid gezond vs. stressgerelateerde aandoening)

Tabel 3 Afkappunten, sensitiviteit en specificiteit van de DASS-42-subschalen voor het detecteren van mensen met een stressgerelateerde aandoening (onderscheid gezond vs. stress)

\begin{tabular}{|c|c|c|c|}
\hline DASS-42-subschaal & waarde & sensitiviteit & specificiteit \\
\hline Depressie & $\begin{array}{c}2 \\
3 \\
4 \\
5 \\
6 \\
7 \\
8 \\
9 \\
10\end{array}$ & $\begin{array}{l}0,95 \\
0,92 \\
0,88 \\
0,85 \\
0,82 \\
0,78 \\
0,76 \\
0,73 \\
0,70\end{array}$ & $\begin{array}{l}0,51 \\
0,62 \\
0,71 \\
0,75 \\
0,78 \\
0,83 \\
0,85 \\
0,87 \\
0,89\end{array}$ \\
\hline Angst & $\begin{array}{l}1 \\
2 \\
3 \\
4 \\
5 \\
6 \\
7 \\
8 \\
9\end{array}$ & $\begin{array}{l}0,93 \\
0,86 \\
0,81 \\
0,73 \\
0,66 \\
0,60 \\
0,57 \\
0,52 \\
0,47\end{array}$ & $\begin{array}{l}0,46 \\
0,67 \\
0,79 \\
0,85 \\
0,89 \\
0,91 \\
0,93 \\
0,95 \\
0,96\end{array}$ \\
\hline Stress & $\begin{array}{c}5 \\
6 \\
7 \\
8 \\
9 \\
10 \\
11 \\
12 \\
13\end{array}$ & $\begin{array}{l}0,93 \\
0,90 \\
0,88 \\
0,86 \\
0,84 \\
0,82 \\
0,79 \\
0,77 \\
0,73\end{array}$ & $\begin{array}{l}0,53 \\
0,59 \\
0,66 \\
0,69 \\
0,73 \\
0,79 \\
0,83 \\
0,86 \\
0,89\end{array}$ \\
\hline
\end{tabular}

NB: het afkappunt dat geadviseerd wordt, is vetgedrukt. Een stressgerelateerde stoornis wordt geconcludeerd indien score $\geq$ afkappunt. 
lijke afkappunten weer van de subschalen van de verkorte DASS, voor wat betreft het detecteren van mensen met een stressgerelateerde aandoening. Afhankelijk van de sensitiviteit en de specificiteit die men nastreeft, kan men een keuze maken uit de gepresenteerde afkappunten.

Tabel 4 Afkappunten, sensitiviteit en specificiteit van de DASS-21-subschalen voor het detecteren van mensen met een stressgerelateerde aandoening (onderscheid gezond vs. stress)

\begin{tabular}{lccc}
\hline DASS-21-subschaal & waarde & sensitiviteit & specificiteit \\
\hline Depressie & 2 & 0,88 & 0,67 \\
& $\mathbf{3}$ & 0,80 & 0,77 \\
& 4 & 0,75 & 0,85 \\
& 5 & 0,69 & 0,89 \\
Angst & 6 & 0,60 & 0,92 \\
& 1 & 0,87 & 0,63 \\
& 2 & 0,76 & 0,82 \\
& 3 & 0,67 & 0,88 \\
Stress & 4 & 0,56 & 0,92 \\
& 5 & 0,47 & 0,95 \\
& 4 & 0,89 & 0,67 \\
& 5 & 0,85 & 0,74 \\
& 6 & 0,79 & 0,83 \\
& 7 & 0,74 & 0,89 \\
& 8 & 0,66 & 0,95 \\
\hline
\end{tabular}

NB: het afkappunt dat geadviseerd wordt, is vetgedrukt. Een stressgerelateerde stoornis wordt geconcludeerd indien score $\geq$ afkappunt.

Afkappunten DASS-42 voor detecteren angststoornis. Figuur 2 geeft de ROCcurves weer van de DASS-42 voor het detecteren van mensen met een angststoornis. Deze groep is vergeleken met mensen bij wie een stressgerelateerde aandoening was vastgesteld. Het gebied onder de curve, als indicatie voor het discriminerend vermogen, was .68. Over het algemeen wordt een waarde van

ROC curves DASS-42

Criterium: angst

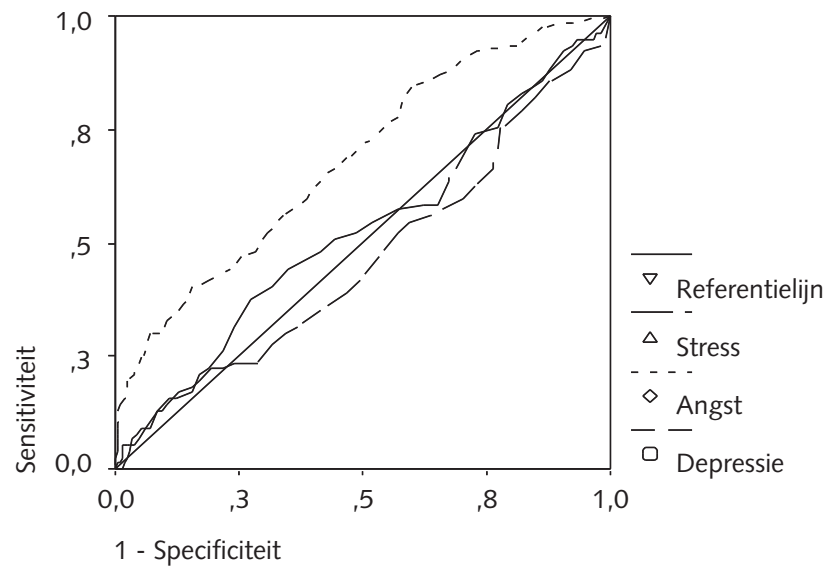


.70 of hoger als acceptabel geacht (Hosmer \& Lemeshow, 2000). Ter vergelijking, het discriminerend vermogen van de depressie- en stressschalen was .46 respectievelijk .53. Tabel 5 geeft de sensitiviteit en de specificiteit van mogelijke afkappunten weer van de angstschalen van de DASS, voor wat betreft het detecteren van mensen met een angstaandoening. Afhankelijk van de sensitiviteit en de specificiteit die men nastreeft, kan men een keuze maken uit de gepresenteerde afkappunten.

Tabel 5 Afkappunten, sensitiviteit en specificiteit van de DASS-42-angstschaal voor detecteren van mensen met een angststoornis (onderscheid stress vs. angst)

\begin{tabular}{lccc}
\hline DASS-42-subschaal & waarde & sensitiviteit & specificiteit \\
\hline Angst & 2 & 0,97 & 0,14 \\
& 3 & 0,94 & 0,19 \\
4 & 0,92 & 0,27 \\
& 5 & 0,87 & 0,34 \\
6 & 0,84 & 0,40 \\
& 7 & 0,78 & 0,43 \\
& 8 & 0,73 & 0,49 \\
& 9 & 0,69 & 0,53 \\
& 10 & 0,64 & 0,59 \\
\hline
\end{tabular}

NB: het afkappunt dat geadviseerd wordt, is vetgedrukt. Angst wordt geconcludeerd indien score $\geq$ afkappunt.

Afkappunten DASS-21 voor detecteren angstaandoening. De ROC-curves van de verkorte DASS voor het detecteren van mensen met een angstaandoening zijn vrijwel gelijk aan die van de DASS-42. Het gebied onder de curve van de angstschaal was .67 en het discriminerend vermogen van de depressie- en stressschalen was wederom laag (AUC .48 resp. .49). De berekening van de afkappunten van de angstschaal is weergegeven in tabel 6. Afhankelijk van de sensitiviteit en de specificiteit die men nastreeft, kan men een keuze maken uit de gepresenteerde afkappunten.

Tabel 6 Afkappunten, sensitiviteit en specificiteit van de DASS-21-angstschaal voor detecteren van mensen met een angststoornis (onderscheid stress vs. angst)

\begin{tabular}{lccc}
\hline DASS-21-subschaal & waarde & sensitiviteit & specificiteit \\
\hline Angst & 1 & 0,87 & 0,13 \\
& 2 & 0,76 & 0,24 \\
& 3 & 0,67 & 0,33 \\
& 4 & 0,56 & 0,44 \\
& 5 & 0,47 & 0,53
\end{tabular}

NB: het afkappunt dat geadviseerd wordt, is vetgedrukt. Angst wordt geconcludeerd indien score $\geq$ afkappunt.

Afkappunten DASS-42 voor detecteren depressie. Figuur 3 geeft de ROC-curves weer van de subschalen van de volledige DASS voor het detecteren van mensen met een depressie. Deze groep is vergeleken met mensen met een stressgerelateerde aandoening. Het discriminerend vermogen van de depressieschaal bleek hierbij acceptabel: het gebied onder de curve bedroeg .70. Ter vergelijking, het discriminerend vermogen van de angst- en stressschalen was laag (AUC .60 resp. .57). Tabel 7 geeft de afkappunten weer van de depressieschaal voor het detecteren van een depressie. 


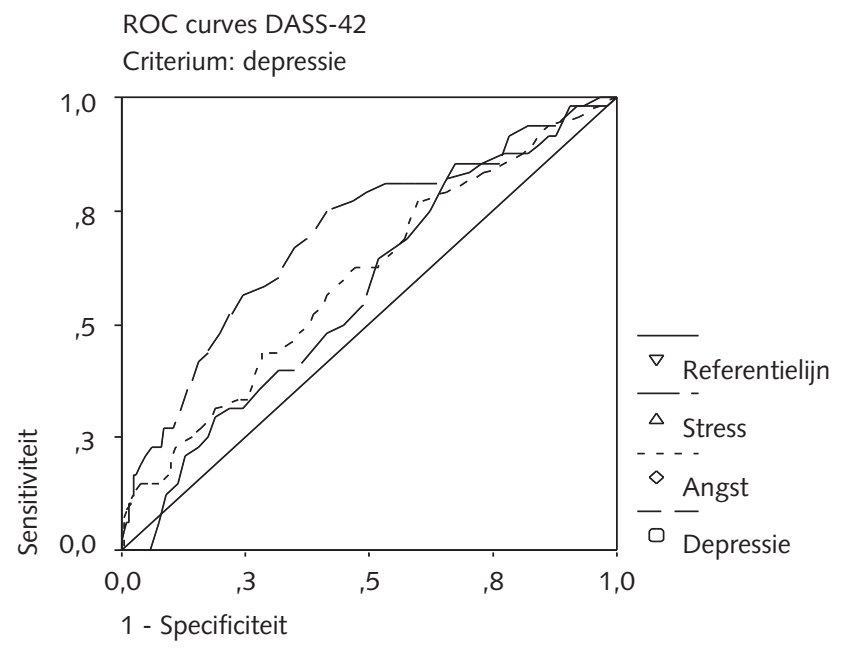

Figuur 3 ROC-curves van de DASS-42-subschalen voor het detecteren van mensen met een depressie (onderscheid stressgerelateerde aandoening vs. depressie)

Tabel 7 Afkappunten, sensitiviteit en specificiteit van de DASS-42-depressieschaal voor het detecteren van mensen met een depressie (onderscheid stress vs. depressie)

\begin{tabular}{lccc}
\hline DASS-42-subschaal & waarde & sensitiviteit & specificiteit \\
\hline Depressie & 13 & 0,81 & 0,43 \\
& 14 & 0,81 & 0,47 \\
15 & 0,79 & 0,50 \\
16 & 0,77 & 0,53 \\
17 & 0,75 & 0,58 \\
18 & 0,69 & 0,63 \\
19 & 0,67 & 0,65 \\
20 & 0,60 & 0,68 \\
21 & 0,58 & 0,71 \\
\hline
\end{tabular}

NB: het afkappunt dat geadviseerd wordt, is vetgedrukt. Depressie wordt geconcludeerd indien score $\geq$ afkappunt.

Afkappunten DASS-21 voor detecteren depressie. De ROC-curves van de subschalen van de verkorte DASS voor het detecteren van mensen met een depressie zijn vergelijkbaar met die van de DASS-42. Het discriminerend vermogen van de depressieschaal was hierbij opnieuw acceptabel (AUC .70), van de angst- en stressschalen was het opnieuw laag (AUC .61 resp. .56). De afkappunten zijn voor de depressieschaal berekend (zie tabel 8). Afhankelijk van de sensitiviteit en de specificiteit die men nastreeft, kan men een keuze maken uit de gepresenteerde afkappunten.

\section{Discussie}

In het huidige onderzoek werd onderzocht in hoeverre de Depression Anxiety Stress Scales (DASS) onderscheid kan maken tussen verschillende categorieën van psychische aandoeningen. Bij proefpersonen uit vier verschillende steekproeven werd bekeken in hoeverre de DASS onderscheid weet te maken tussen 
Tabel 8 Afkappunten, sensitiviteit en specificiteit van de DASS-21 depressieschaal voor het detecteren van mensen met een depressie (onderscheid stress vs. depressie)

\begin{tabular}{lccc}
\hline DASS-21 subschaal & waarde & sensitiviteit & specificiteit \\
\hline Depressie & 6 & 0,82 & 0,40 \\
& 7 & 0,82 & 0,48 \\
& 8 & 0,74 & 0,56 \\
& 9 & 0,72 & 0,62 \\
& 10 & 0,68 & 0,70 \\
\hline
\end{tabular}

NB: het afkappunt dat geadviseerd wordt, is vetgedrukt. Depressie wordt geconcludeerd indien score $\geq$ afkappunt.

mensen zonder psychische aandoening (gezonde mensen), mensen met een stressgerelateerde stoornis, mensen met een klinische angststoornis en mensen met een klinische depressie.

\subsection{Detecteren stressgerelateerde stoornis}

Allereerst is onderzocht in hoeverre de DASS-schalen mensen met een stressgerelateerde stoornis kunnen detecteren. Mensen met een stressgerelateerde stoornis rapporteren, in vergelijking met gezonde mensen, meer stressklachten, depressieve klachten en angstklachten, gemeten met de DASS. Voorts blijken alle DASS-schalen goed te differentiëren tussen deze beide groepen. Voor alle schalen van de DASS (verkorte en uitgebreide versie) worden dan ook mogelijke afkappunten geadviseerd. Hoewel de specificiteit belangrijk is om onnodige medicalisering te voorkomen, wordt in de huidige studie met name de sensitiviteit van belang geacht. De consequenties van onterecht concluderen dat er geen sprake is van een stressgerelateerde, angst- of depressieve stoornis zijn, in de huidige context van het onderzoek, ernstiger dan het onterecht concluderen dat er wel sprake is van een stoornis. In dit onderzoek is dan ook gekozen voor afkappunten met een minimale sensitiviteit van .80 , een gangbare normwaarde voor de power van een onderzoek (Cohen, 1977). Afhankelijk van de sensitiviteit en de specificiteit die men nastreeft, kan men ook een eigen keuze maken uit de gepresenteerde afkappunten.

Opvallend is dat de stressschalen niet beter blijken te discrimineren dan de depressie- en angstschalen tussen gezonde mensen en mensen met een stressgerelateerde stoornis. Stressgerelateerde stoornissen worden dus niet alleen gekenmerkt door stressgerelateerde klachten, maar ook door een verhoogd niveau van angst- en depressieve klachten. Daarnaast blijken ook angst- en depressieve stoornissen gepaard te gaan met een verhoogd niveau van stressklachten. Deze laatste bevinding sluit goed aan op het tripartiete model (Clark \& Watson, 1991). In het tripartiete model worden de verschillen tussen angst- en depressiesymptomen genoemd, maar wordt ook de overlap benadrukt: symptomen van algemene malaise of negatief affect zouden zowel bij angst- als bij stemmingsstoornissen voorkomen. De stressschaal van de DASS heeft voor een deel betrekking op deze non-specifieke symptomen van angst en depressie (de Beurs et al., 2001).

\subsection{Detecteren angststoornis}

In het huidige onderzoek is ook nagegaan in hoeverre de DASS-schalen een klinische angststoornis kunnen detecteren. Mensen met een angststoornis 
rapporteren, in vergelijking met mensen met een stressgerelateerde stoornis, meer angstklachten. Ze scoren echter niet hoger op depressieve klachten of stressklachten. In overeenstemming met deze bevinding, blijken alleen de angstschalen te differentiëren tussen beide groepen, al was het discriminerend vermogen iets minder dan over het algemeen als acceptabel wordt beschouwd. De bevinding dat alleen de angstschaal in redelijke mate discrimineert, ondersteunt de validiteit van deze schaal. Voor zowel de DASS-42 als de DASS-21 zijn dan ook mogelijke afkappunten van de angstschalen berekend.

\subsection{Detecteren depressie}

In het huidige onderzoek is voorts onderzocht in hoeverre de DASS-schalen goed in staat zijn mensen met een klinische depressie te detecteren. Mensen met een depressieve stoornis blijken, in vergelijking met mensen met een stressgerelateerde stoornis, hoger te scoren op de depressieschalen. Dit blijkt echter niet te gelden voor de angst- en stressschalen. In overeenstemming met het voorgaande, blijken alleen de depressieschalen te differentiëren tussen beide groepen. Dit ondersteunt de validiteit van de depressieschalen. Voor zowel de DASS-42 als de DASS-21 zijn mogelijke afkappunten voor de depressieschaal gepresenteerd.

\subsection{Het belang van de stressschaal?}

Uit bovenstaande analyses zou men kunnen afleiden dat voor het detecteren van stressgerelateerde, angst- of depressieve stoornis volstaan kan worden met de angst- en depressieschalen. ${ }^{2}$ De stressschalen voegen voor het detecteren van een stressgerelateerde stoornis weinig toe aan de overige schalen. Bovendien is het discriminerend vermogen van de stressschalen voor het detecteren van een angststoornis of depressie laag. Niettemin kunnen de stressschalen van groot belang zijn voor het verkrijgen van inzicht in stressgerelateerde problematiek van individuele patiënten. Daarnaast zijn de stressschalen van de DASS van grote waarde omdat de DASS zich niet specifiek op de werksituatie richt (zie de Beurs et al., 2001). In tegenstelling tot andere instrumenten, zoals de Utrechtse Burnout Schaal (UBOS, de Nederlandse versie van de Maslach Burnout Inventory; Schaufeli \& Van Dierendonck, 1994), is de DASS derhalve geschikt om ook bij personen stressklachten te meten die zich rond het moment van meten niet in een werksituatie bevinden, zoals zieke werknemers.

\subsection{Relevantie voor de arbocuratieve zorg}

Het huidige onderzoek toont het discriminerend vermogen van zowel de DASS-42 als de DASS-21 aan. De DASS is daarmee van grote waarde voor de arbocuratieve zorg. Het is voor bedrijfsartsen van groot belang om snel en op relatief weinig ingrijpende wijze mensen met een stressgerelateerde stoornis te kunnen detecteren en te bepalen wanneer er sprake is van ernstige psychopathologie, zoals een angst- of depressieve stoornis. Op deze wijze kunnen interventies effectiever worden ingezet. Binnen de arbocuratieve zorg zou de DASS bij voorkeur in een ketenanalyse kunnen worden geplaatst. Bij zieke werknemers waarbij het vermoeden is dat er psychische klachten aanwezig 
zijn, neemt men eerst de (verkorte) DASS af. Eventueel kan daarna, bij een score gelijk aan of hoger dan de grenswaarde voor wat betreft angst of depressie, een ander instrument worden ingezet dat zich specifiek richt op het vaststellen van een klinische depressie of een klinische angststoornis, zoals bijvoorbeeld de MINI (Sheehan et al., 1998). De bedrijfsarts kan dit interview zelf afnemen, maar kan ook besluiten de werknemer voor verdere diagnose door te verwijzen naar een GZ-psycholoog of klinisch psycholoog. Op deze wijze kan meer inzicht worden verkregen in de aard en ernst van de specifieke stoornis van de cliënt. Wanneer de cliënt lager scoort dan de grenswaarde voor wat betreft stress, dan zou de bedrijfsarts eventueel een lichtere vorm van begeleiding kunnen geven dan gebruikelijk is in het geval van een stressgerelateerde stoornis.

Uit de resultaten komt naar voren dat de 21-itemversie van de DASS niet onderdoet in discriminerend vermogen voor de 42 -itemversie. Dat doet de vraag rijzen of het zinvol is de patiënt te belasten met extra vragen als men met 21 vragen al redelijk nauwkeurig kan bepalen of personen aan een stressgerelateerde stoornis of zelfs aan een psychiatrische stoornis lijden. Het antwoord op deze vraag hangt af van de doelstelling bij gebruik van de DASS. Gaat het alleen om de klinische vraag of nader diagnostisch onderzoek gewenst is, dan volstaat de verkorte DASS; is men geïnteresseerd in een nauwkeurig beeld van de mate van depressie, angst en/of stress bij de patiënt, dan geeft de 42-itemversie van de DASS een beter beeld.

\subsection{Kanttekeningen}

Een belangrijke kanttekening bij het huidige onderzoek is dat 'gezonde' personen niet waren gediagnosticeerd op psychische aandoeningen. De veronderstelling was dat deze mensen, die geen claim wegens ziekte of arbeidsongeschiktheid hadden ingediend, gezond waren en derhalve niet zouden voldoen aan de voorwaarden voor een psychische stoornis. Het is echter mogelijk dat een klein deel van deze niet-verzuimende steekproef toch zodanige psychische klachten ervaart dat gesproken kan worden van een psychische stoornis. Uit prevalentieonderzoek is naar voren gekomen dat 10 tot $20 \%$ van de 'gezonden' voldoet aan diagnostische criteria van een psychiatrische stoornis (Bijl, Ravelli \& Van Zessen, 1998). Voor vervolgonderzoek wordt aangeraden 'gezonde' groepen, voorzover mogelijk, te diagnosteren op afwezigheid van psychische aandoeningen of op zijn minst te bevragen omtrent huidig gebruik van GGZ-voorzieningen.

Een tweede kanttekening betreft de wijze waarop de diagnose stressgerelateerde stoornis is vastgesteld. In de onderzoeken van Blonk et al. (2004) en Nieuwenhuijsen et al. (2003) werd een stressgerelateerde stoornis geconcludeerd indien personen, die aangaven wegens psychische klachten te verzuimen, geen ernstige psychopathologie rapporteerden. In sommige gevallen kan het hierbij echter gaan om (chronische) neurotische problematiek, waarbij arbeidsomstandigheden geen belangrijke rol spelen. In dergelijke gevallen zou verwijzing naar een eerstelijns psycholoog of RIAGG meer voor de hand liggen dan behandeling door de bedrijfsarts zelf.

Een derde kanttekening bij dit onderzoek betreft de vergelijkbaarheid van de verschillende databestanden die in deze studie zijn gebruikt. Allereerst verschillen de steekproeven voor wat betreft werknemerschap: in twee databestanden betreft het zelfstandig ondernemers, zieke ondernemers (Blonk et al., 2004) of gezonde ondernemers (Lagerveld et al., 2004); in het databestand van 
Nieuwenhuijsen et al. (2003) gaat het om zieke werknemers; en in het databestand van De Beurs et al. (2001) gaat het om een patiëntenpopulatie van wie niet bekend is of ze werknemer zijn of niet. Daarnaast is de diagnostiek van psychische problematiek niet in elk onderzoek op dezelfde wijze uitgevoerd: in het onderzoek van Blonk et al. en Nieuwenhuijsen et al. zijn door de onderzoekers CIDI's (Composite International Diagnostic Interview, WHO, 1997) afgenomen, terwijl in het onderzoek van De Beurs et al. de diagnose werd gesteld door de behandelend psycholoog of psychiater op grond van zijn/haar klinisch oordeel, waarbij de DSM-IV-criteria (APA, 1994) gehanteerd werden. Het verdient aanbeveling om in de verdere ontwikkeling van afkappunten ook een populatie van gezonde werknemers te betrekken en de diagnostiek, voorzover mogelijk, volgens een identieke methode uit te voeren.

\subsection{Conclusie}

Deze studie laat het discriminerend vermogen van de DASS zien voor het detecteren van een stressgerelateerde stoornis, een klinische angststoornis en depressie. Dit geldt zowel voor de verkorte DASS (DASS-21) als voor de uitgebreide DASS (DASS-42). Voor de arbocuratieve zorg is de DASS derhalve een bruikbaar instrument, dat de kwaliteit van de diagnose verder kan verbeteren en een effectieve inzet van interventies voor zieke werknemers kan bevorderen.

\section{Noten}

1 Om te controleren voor demografische variabelen, is ook een MANOVA (GLM) uitgevoerd met de scores op de DASS-subschalen als afhankelijke variabelen, diagnosegroep als onafhankelijke variabele en leeftijd en geslacht als covariaat. De verschillen tussen diagnosegroepen zijn multivariaat significant $(F(18,2373)=37.69, p<.05)$, en univariaat significant voor elk van de subschalen $\left(p^{\prime} s<.05\right)$.

2 Naar aanleiding van de resultaten in dit onderzoek, kan men zich afvragen of men de totaalscore op de DASS zou kunnen gebruiken voor het detecteren van stressgerelateerde stoornissen en ernstiger psychopathologie. Additionele analyse wijst uit dat het discriminerend vermogen van de totale DASS-42 en DASS-21 voor het detecteren van een stressgerelateerde stoornis goed is (AUC voor beide schalen .90). Voor het detecteren van een angststoornis is het discriminerend vermogen echter onvoldoende (AUC .56 en .55). Voor het detecteren van een depressieve stoornis bedraagt de AUC voor beide schalen .65. Het lijkt derhalve raadzaam de afzonderlijke scores op de subschalen te gebruiken, en niet de totaalscore.

\section{Literatuur}

APA (American Psychiatric Association; 1994). Diagnostic and statistical manual of mental disorders (4th ed.). Washington, DC: APA.

Bijl, R.V., Ravelli, A. \& Zessen, G. van (1998). Prevalence of psychiatric disorder in the general population: Results of the Netherlands Mental Health Survey and Incidence Study (NEMESIS). Social Psychiatry and Psychiatric Epidemiology, 33, 587-595.

Blonk, R.W.B., Lagerveld, S.E., Brenninkmeijer V. \& Houtman, I.L.D. (2004). Prevention of work disability due to psychological complaints among self-employed: a randomised field experiment. Manuscript aangeboden ter publicatie.

Beurs, E. de, Dyck, R. van, Marquenie, L.A., Lange, A. \& Blonk, R.W.B. (2001). De DASS: Een vragenlijst voor het meten van depressie, angst en stress. Gedragstherapie, 34, 35-53. 
Brown, T.A., Chorpita, B.F., Korotitsch, W. \& Barlow, D.H. (1997). Psychometric properties of the Depression Anxiety Stress Scales (DASS) in clinical samples. Behaviour Research and Therapy, 35, 79-89.

Clark, L.A. \& Watson, D. (1991). A tripartite model of anxiety and depression: Psychometric evidence and taxonomic implications. Journal of Abnormal Psychology, 100, 316-336.

Cohen, J. (1977). Statistical power analysis for the behavioral sciences. New York: Academic Press.

Fenig, S., Levav, I., Kohn, R. \& Yelin, N. (1993). Telephone versus face-face interviewing in a community psychiatric survey. American Journal of Public Health, 83, 896-898.

Hoofdakker, R.H. van de, Albersnagel, F.A. \& Ormel, J. (1989). Begripsbepaling, syndromale classificatie, differentiële diagnostiek, casuïstiek en epidemiologie. In F.A. Albersnagel, P.M.G. Emmelkamp, \& R.H. van den Hoofdakker (Red.), Depressie: Theorie, diagnostiek en behandeling. Deventer: Van Loghum Slaterus.

Hosmer, D.W. \& Lemeshow, S. (2000). Assessing the fit of the model. Applied logistic regression, 160-164. New York: Wiley \& Sons.

Klink, J.J.L. van der, Blonk, R.W.B., Schene, A.H. \& Dijk, F.J.H. van (2003). Reducing long term sickness absence by an activating intervention in adjustment disorders: A cluster randomized controlled design. Occupational and Environmental Medicine, 60, 429-437.

Lagerveld, S.E., Blonk, R.W.B., Croon, E.M. de \& Houtman, I.L.D. (2004). Comparison of the JCQ and ERI models in predicting work related psychological complaints: A longitudinal study amongst self-employed. Manuscript aangeboden ter publicatie.

Lange, A., Ven, J.P. van de, Schrieken, B. \& Smit, M. (2003). Interapy-Burnout: Preventie en behandeling van burnout via het internet. Directieve Therapie, 23(2), 121-145.

Lovibond, S.H. \& Lovibond, P.F. (1995a). Manual for the Depression Anxiety Stress Scales. Sydney, The Psychology Foundation of Australia.

Lovibond, S.H. \& Lovibond, P.F. (1995b). The structure of negative emotional states: Comparison of the Depression Anxiety Stress Scales (DASS) with the Beck Depression and Anxiety Inventories. Behaviour Research and Therapy, 33, 335-342.

NCvB (Nederlands Centrum voor Beroepsziekten; 2003). Signaleringsrapport beroepsziekten 03. Amsterdam: NCvB.

Nieuwenhuijsen, K., Boer, A.G.E.M. de, Verbeek, J.H.A.M., Blonk, R.W.B. \& Dijk, F.J.H. van (2003). The Depression Anxiety Stress Scales (DASS): Detecting anxiety disorder and depression in employees absent from work because of mental health problems. Occupational and Environmental Medicine, 60 (Supplement I), 77-82.

NVAB (Nederlandse Vereniging voor Arbeids- en Bedrijfsgeneeskunde; 2000). Richtlijnen voor bedriffsartsen. Handelen van de bedrijfsarts bij werknemers met psychische klachten. http://www.richtlijnen-nvab.nl/downloadables/rl_pk.pdf

Schaufeli, W.B. \& Dierendonck, D. van (1994). Burnout, een begrip gemeten. De Nederlandse versie van de Maslach Burnout Inventory (MBI-NL). Gedrag en Organisatie: Tijdschrift voor Psychologie en Gezondheid, 22, 153-172.

Sheehan, D.V., Lecrubier, Y., Sheehan, K.H., Amorim, P., Janavs, J., Weiller, E., Hergueta, Th., Baker, R. \& Dunbar, G.C. (1998). The Mini-International Neuropsychiatric interview (MINI): The development and validation of a structured diagnostic psychiatric interview for DSM-IV and ICD-10. Journal of Clinical Psychiatry, 59, 22-33.

UWV (Uitvoering Werknemersverzekeringen; 2003). Ontwikkeling arbeidsongeschiktheid: Jaaroverzicht WAO/WAZ/Wajong 2002. www.uwv.nl

WHO (World Health Organization; 1997). Composite International Diagnostic Interview (CIDI), version 2.1. WHO. 


\section{Summary}

The value of the DASS in absence policies:

Sensitivity and specificity of a psychopathology measure

Veerle Brenninkmeijer, Roland W.B. Blonk, Karen Nieuwenhuijsen \& Edwin de Beurs, Gedrag \& Organisatie, Volume 18, August 2005, pp. 210-227

In the present study we examined to what extent the DASS (Depression Anxiety Stress Scales) is able to discriminate between healthy individuals, individuals with a stress-related disorder, and individuals with more serious psychopathology (anxiety or affective disorder). Differences between groups were first examined with a one-way analysis. Using ROC-curves we subsequently determined the discriminative power and the cut-off points of the DASS. This study shows the discriminative power of the DASS-42 and the DASS-21 in detecting a stress-related disorder, a clinical anxiety disorder, and depression. It is concluded that the DASS is a highly useful instrument for occupational health care, which can improve an effective use of interventions for sick employees.

Keywords: DASS (Depression Anxiety Stress Scales), stress-related disorder, clinical anxiety disorder, depression, absence policies 